\title{
DETERMINAN KEGAGALAN PEMBERIAN ASI EKSKLUSIF PADA IBU RUMAH TANGGA DI KECAMATAN MARGA
}

\author{
Hesteria Friska Armynia S. ${ }^{1,2}$, Indra Peratiwi ${ }^{1,2}$ \\ ${ }^{1}$ Program Studi DIII Kebidanan, ${ }^{2}$ Stikes Advaita Medika Tabanan \\ Korespondensi penulis: hesteria.friska@yahoo.com
}

\begin{abstract}
Abstrak
Latar belakang dan tujuan: (WHO) merekomendasikan pemberian ASI eksklusif selama 4-6 bulan. Namun, pada tahun 2001, melalui telaah artikel penelitian secara sistematik dan berkonsultasi dengan para pakar, WHO merevisi rekomendasi ASI eksklusif tersebut dari 4-6 bulan menjadi 6 bulan. Hasil telaah artikel tersebut menyimpulkan bahwa bayi yang disusui secara eksklusif sampai 6 bulan umumnya lebih sedikit menderita penyakit gastrointestinal, dan lebih sedikit mengalami gangguan pertumbuhan. Tujuan penelitian ini adalah untuk mengetahui faktorfaktor yang menjadi penyebab kegagalan ibu rumah tangga dalam memberikan eksklusif pada bayinya di Kecamatan Marga.

Metode: Rancangan penelitian ini adalah kualitatif. Pengumpulan data dilakukan pada ibu rumah tangga yang tidak memberikan ASI eksklusif pada anaknya. Penelitian menggunakan metode wawancara mendalam kepada 16 informan, dan diambil dengan cara purposive yang terdiri dari ibu rumah tangga, suami dan keluarga. Data dianalisis menggunakan metode tematik.

Hasil: Dalam penelitian ini ditemukan beberapa faktor yang menjadi penyebab kegagalan ASI Eksklusif pada balita usia 6 bulan seperti faktor predisposisi (pengetahuan, pendidikan, kepercayaan, usia dan pendapatan keluarga), faktor pemungkin (cara lahir, IMD, rooming in, kondisi bayi, kondisi ibu dan paritas ibu) dan faktor penghambat (kondisi ibu, waktu, psikologis ibu, kurangnya dukungan keluarga dan tenaga kesehatan). Ketiga faktor tersebutlah yang menjadi alasan ibu rumah tangga tidak bisa memberikan ASI Eksklusif pada anaknya.

Simpulan: Ada beberapa faktor yang menjadi penyebab kegagalan pemberian ASI Ekslusif seperti faktor predisposisi, faktor pemungkin serta penghambat. Sehingga diperlukan adanya edukasi danpendekatan dari keluarga dan tenaga kesehatan supaya semua ibu rumah tangga mau memberikan ASI Eksklusif.
\end{abstract}

Kata kunci: Faktor predisposisi, pemungkin, penguat, kegagalan, ASI Eksklusif, ibu rumah tangga

\section{Pendahuluan}

(WHO) merekomendasikan pemberian ASI eksklusif selama 4-6 bulan. Namun, pada tahun 2001, melalui telaah artikel penelitian secara sistematik dan berkonsultasi dengan para pakar, WHO merevisi rekomendasi ASI eksklusif tersebut dari 4-6 bulan menjadi 6 bulan. Hasil telaah artikel tersebut menyimpulkan bahwa bayi yang disusui secara eksklusif sampai 6 bulan umumnya lebih sedikit menderita penyakit gastrointestinal, dan lebih sedikit mengalami gangguan pertumbuhan. ASI eksklusif adalah pemberian hanya ASI tanpa cairan atau makanan padat apapun kecuali vitamin, mineral atau obat dalam bentuk tetes atau sirup sampai bayi berusia 6 bulan. Berbagai penelitian telah mengkaji manfaat pemberian ASI eksklusif dalam menurunkan mortalitas bayi, menurunkan morbiditas bayi, mengoptimalkan pertumbuhan bayi, membantu perkembangan kecerdasan anak,dan membantu memperpanjang jarak kehamilan bagi ibu. (Depkes, 2001)

Pemerintah Indonesia telah menghimbau pemberian ASI ekslusif karena pada dasarnya 
tingkat pemberian ASI juga masih rendah. Pemerintah juga telah menerapkan berbagai regulasi dan peningkatan layanan di banyak tempat seperti Peraturan Pemerintah Nomor 33 Tahun 2012 yang mengatur larangan fasilitas layanan kesehatan menawarkan dan memberikan susu formula. Penelitian menunjukkan di Indonesia sekitar 1,5 juta anak meninggal akibat dari pemberian makanan yang salah. Hal itu didukung fakta bahwa tingkat pemberian ASI kurang dari $15 \%$ dan hanya diberikan selama 4 bulan pertama kemudian didukung juga oleh pemberian makan makanan pendamping ASI yang salah dan tidak tepat untuk bayi (Kementerian Kesehatan RI, 2014).

Target cakupan pemberian ASI ekslusif di Indonesia adalah $80 \%$ namun berdasarkan hasil pendataan dalam Riset Kesehatan Dasar (Riskesdas) pada tahun 2010 rata-rata pemberian ASI nasional sebesar 15,3\% dan mengalami peningkatan yang tidak signifikan pada tahun 2013 menjadi 30,2\%. Hasil riset ini menunjukkan masih kurangnya pemberian ASI dan nutrisi untuk anak-anak Indonesia. Padahal pada dasarnya ASI sangat diperlukan dan penting dalam proses pertumbuhan anak baik secara mental maupun fisik dan berdampak dalam jangka waktu yang sangat panjang. Dari hasil Riskesdas 2013, didapatkan pula data jenis makanan prelakteal yang paling banyak diberikan ke bayi adalah susu formula sebesar 79,8\%. Provinsi Bali menempati peringkat ke dua cakupan tertinggi susu formula di Indonesia sebesar 93,7\%.

Di provinsi Bali dalam 5 tahun terakhir, cakupan pemberian ASI ekslusif sudah mengalami peningkatan namum belum mencapai target nasional sebesar $80 \%$. Dibandingkan dengan cakupan tahun 2009 (46.25\%), pada tahun 2010 turun menjadi $36,54 \%$, tapi kembali naik tajam tahun $58,65 \%$ dan dalam kurun waktu 3 tahun terakhir (tahun 2011, 2012 dan 2013) terus mengalami peningkatan dengan cakupan tahun 2013 sebesar 67,4\%. Cakupan pemberian ASI ekslusif di Kabupaten Tabanan masih di bawah rata-rata Provinsi Bali yaitu sebesar $61,79 \%$ pada tahun 2013 dan mengalami sedikit peningkatan yaitu sebesar $62,24 \%$ pada tahun 2014. Pemberian ASI ekslusif di wilayah kerja Puskesmas Marga I mengalami penurunan yaitu sebesar $70,71 \%$ pada tahun $2013,68,57 \%$ pada tahun 2015, dan turun lagi menjadi 58,62\% pada tahun 2015.

Berdasarkan penelitian Putra (2008) Penyebab kegagalan praktek ASI eksklusif bermacam-macam seperti pemberian makanan prelakteal, ibu harus bekerja, bayi sakit, ibu lelah/sakit, ibu kurang percaya diri, dan lain-lain.Berbagai faktor juga telah dihubungkan dengan rendahnya pengetahuan ibu. Penelitian Wahyuni (2012) menunjukkan bahwa bukan semata-mata factor pengetahuan ibu yang mempengaruhi keberhasilan ASI ekslusif, tetapi ada faktorfaktor lain di luar pengetahuan ibu yang mempengaruhi keberhasilan ASI eksklusif.

Hasil penelitian yang dilakukan oleh Wijaya (2002) mengenai pemberian ASI dan MP-ASI serta status gizi bayi usia 6-8 bulan pada ibu bekerja dan tidak bekerja menunjukkan prosentase pemberian susu formula pada ibu tidak bekerja lebih besar dibandingkan dengan ibu yang bekerja yaitu sebesar $73,3 \%$ pada ibu tidak bekerja dan sebesar 56,7\% pada ibu yang bekerja. Untuk pemberian kolostrom didapatkan prosentase yang lebih besar pada ibu bekerja yaitu sebanyak $96,7 \%$, sedangkan ibu yang tidak bekerja lebih sedikit yaitu sebesar $90 \%$.

Berdasarkan permasalahan diatas, maka diperlukan suatu penelitian kualitatif untuk mengeksplorasi secara mendalam mengenai faktor-faktor yang menjadi penyebab kegagalan pemberian ASI eksklusif pada ibu rumah tangga di Kecamatan Marga sehingga dapat dijadikan dasar pengembangan guna meningkatkan cakupan pemberian ASI eksklusif.

\section{Metode Penelitian}

Penelitian mengenai alasan kegagalan pemberian ASI eksklusif pada ibu rumah tangga menggunakan rancangan kualitatif. Pendekatan tersebut dipilih agar dapat mengeksplorasi persepsi ibu rumah tangga mengenai alasan kegagalan pemberian ASI 
eksklusif pada anaknya secara lebih mendalam. Dalam pengambilan data pada penelitian ini menggunakan dua bahasa yaitu bahasa daerah dan bahasa Indonesia.

Namun dalam penyusunan hasil penelitian ini peneliti menggunakan bahasa Indonesia. Lokasi penelitian ini adalah mereka yang terkait dalam pemberian ASI eksklusif di kecamatan Marga seperti ibu rumah tangga, suami dan keluarga terdekat. Penelitian ini telak dilaksanakan sejak bulan Maret 2019 dan direncanakan akan berlangsung hingga bulan November 2019 . Jenis data dalam penelitian ini adalah data kualitatif yang berupa wawancara mendalam terhadap ibu rumah tangga tentang alasan kegagalan ASI Eksklusif pada ibu bekerja di Kecamatan Marga.

Instrumen penelitian ini menggunakan pedoman wawancara yang langsung ditanyakan kepada para informan. Pengumpulan data dalam penelitian ini yakni wawancara mendalam. Proses pencatatan dapat dibantu dengan menggunakan instrumen. Proses wawancara mendalam yaitu dengan mengajukan beberapa pertanyaan kepada para informan. Analisis data pada penelitian ini dilakukan dengan mengorganisasikan data, menjabarkannya kedalam unit-unit, melakukan sintesa, menyusun ke dalam pola, memilih mana yang penting, dan membuat kesimpulan, sehingga dapat diceritakan kepada orang lain. Prosedur pengolahan data pada penelitian ini dimulai dengan pemrosesan dokumentasi. Hasil dari wawancara mendalam yang telah direkam ke dalam alat perekam serta didengarkan berulang-ulang dipindahkan ke dalam bentuk verbatin yang kemudian digabung dengan catatan di lapangan. Hasil verbatin dibuat dalam bentuk transkrip. Hasil transkrip dibaca berulang-ulang dan didengarkan kembali untuk memastikan keakuratannya. Kode dilakukan untuk memudahkan analisis data terhadap kata kunci dari informan yang satu dengan informan yang lainnya.

\section{Hasil dan Pembahasan}

Dalam penelitian ditemukan beberapa faktor yang menjadi penyeyebab kegagalan ASI eksklusif pada ibu rumah tangga, seperti yang dikemukakan dibawah ini:

\section{Faktor Predisposisi}

Faktor predisposisi yaitu faktor pemicu atau pemudah yang memberikan kecenderungan seorang ibu untuk tidak memberikan ASI eksklusif kepada anaknya. Faktor predisposisi pada penelitian ini yaitu pendidikan, pengetahuan, kepercayaan atau persepsi, usia dan pendapatan keluarga.

Pendidikan informan menjadi faktor predisposisi yang menjadikan ibu rumah tangga tidak memberikan ASI ekslusif kepada bayinya. Seluruh informan ASI tidak eksklusif tidak ada satupun yang mengetahui definisi ASI eksklusif dengan benar. Dapat dilihat pada sitasi dibawah ini:

"ASI yang dikasih sampai umur 2 tahun, sambil dikasih susu formula kalo bayinya mau....."

"Hanya ASI saja sampai umur 6 bulan, nggak boleh dikasih makan tapi susu formula sih boleh." (informan-informan ASI tidak eksklusif berpendidikan tinggi)

"ASI yang langsung dari ibu... air susu murni maksudnya, belum dikasih makanan tambahan..." (informan ASI tidak eksklusif berpendidikan rendah)

Dalam penelitian ini pendidikan sangat mempengaruhi jawaban dari informan. Pendidikan merupakan upaya persuasif atau pembelajaran kepada masyarakat agar masyarakat mau melakukan tindakantindakan atau praktik untuk memelihara (mengatasi masalah) dan meningkatkan kesehatannya. Perubahan atau tindakan pemeliharaan dan peningkatan kesehatan yang dihasilkan oleh pendidikan kesehatan ini didasarkan pada pengetahuan serta kesadarannya melalui proses pembelajaran sehingga perilaku tersebut diharapkan akan berlangsung lama dan menetap. Paradigma itu dipicu oleh tingginya tingkat kebutuhan hidup dan pemahaman kaum wanita tentang aktualisasi diri. Pendidikan dan kebebasan informasi membuat para wanita masa kini 
lebih berani memasuki wilayah pekerjaan lain yang dapat memberdayakan kemampuan dirinya secara maksimal sehingga ibu tidak dapat memberikan ASI eksklusif. Pendidikan juga akan membuat seseorang terdorong untuk ingin tahu mencari dan pengalaman sehingga informasi yang diterima akan jadi pemahaman.

Pada penelitian ini tingkat pendidikan ibu yang rendah mengakibatkan kurangnya pengetahuan ibu dalam menghadapi masalah, terutama dalam pemberian ASI eksklusif. Pengetahuan ini diperoleh baik secara formal maupun informal. Sedangkan ibu-ibu yang mempunyai tingkat pendidikan yang lebih tinggi, umumnya terbuka menerima perubahan atau hal-hal guna pemeliharaan kesehatanya. Pendidikan juga akan membuat seseorang terdorong untuk ingin tahu mencari pengalaman sehingga informasi yang diterima akan menjadi pengetahuan.

Tingkat pendidikan dalam penelitian merupakan salah satu aspek sosial yang umumnya berpengaruh pada tingkat pendapatan keluarga sebagai faktor ekonomi. Pendidikan juga dapat mempengaruhi sikap dan tingkah laku manusia. Semakin tinggi tingkat pendidikan ibu, semakin tinggi jumlah ibu tidak memberikan ASI pada bayinya. Hal tersebut senada dalam penelitian yang dilakukan Wahyuni (2012) tingkat pendidikan ibu mempunyai pengaruh dalam pola pemberian ASI, makin tinggi tingkat pendidikan ibu makin rendah prevalensi menyusui secara eksklusif selain itu ibu-ibu berpendidikan sekolah lanjut atas untuk tidak lagi memberikan ASI pada bayinya.

Selain pendidikan, pengetahuan juga menjadi faktor predisposisi seperti hasil penelitian yang didapatkan dibawah ini. Informan ASI tidak eksklusif juga berniat memberikan ASI kepada bayinya. Mereka tahu bahwa ASI perlu diberikan sampai anak berusia 2 tahun, tapi mereka tidak mengetahui bahwa ASI eksklusif atau hanya ASI saja perlu diberikan sampai 6 bulan. Mereka menyebutkan bahwa ASI dapat diberikan digabung dengan makanan atau minuman lain.

“... Iya, pengennya 6 bulan tapi bayinya kayak yang nyusu terus, tidak berhentiberhenti. Menurut ibu bayi lapar, jadi ASI saja sudah tidak cukup ..." (informan ASI tidak eksklusif berpendidikan tinggi) lain..."

"Ya, 2 tahun sambil digabung sama yang

"Ada, cuma tidak tahu ASI eksklusif. Untuk 2 tahun...." (informan-informan ASI tidak eksklusif berpendidikan rendah)

Menurut Soetjiningsih (2001), pengetahuan tentang ASI ekslusif sudah harus diberikan kepada ibu sejak kehamilannya. Penyuluhan tentang hal-hal yang mendukung ibu untuk bisa memberikan ASI ekslusif harus mulai diberikan seperti penyuluhan tentang gizi ibu hamil dan menyusui, keunggulan ASI, manfaat menyusui dan kerugian pemberian susu formula. Informasi tentang ASI ekslusif dapat diperoleh ibu dari bidan, media cetak maupun media elektronik. Pengetahuan ibu tentang manfaat pemberian ASI ekslusif bagi bayi sangat penting dalam menentukan keberhasilan pemberian ASI ekslusif. Hal ini didukung juga oleh hasil penelitian yang menemukan bahwa kurangnya pemahaman ibu terhadap pemberian ASI dan tata cara pemberian ASI yang benar merupakan hambatan utama dalam keberhasilan pemberian ASI ekslusif. Padahal apabila ibu memiliki pemahaman yang benar mengenai pemberian ASI ekslusif dan tata cara pemberiannya, hal tersebut dapat menunjang keberhasilan menyusui (Susanti, 2000).

Hasil penelitian lain yang dikemukakan oleh Bloom mengemukakan bahwa perilaku mencakup 3 aspek yaitu kognitif (pengetahuan), afektif (sikap) dan psikomotorik (tindakan). Untuk bisa memberikan ASI ekslusif, seorang ibu perlu memiliki pengetahuan tentang ASI ekslusif dan bisa membentuk sikap terhadap ASI ekslusif serta mau berindak memberikan ASI ekslusif terhadap bayinya. Pengetahuan dan sikap amat berpengaruh terhadap perilaku 
yang diciptakan. Sebelum terwujud dalam suatu perilaku, faktor keyakinan, norma sosial dan pandangan subyektif amat menentukan sikap seseorang. Dengan beberapa model teori tersebut dapat diartikan bahwa seorang ibu akan memberikan ASI ekslusif apabila ibu bayi memiliki dasar pengetahuan yang kuat mengenai pemberian ASI secara ekslusif berserta manfaatnya dan kerugian yang ditimbulkan apabilan tidak memberikan ASI ekslusif.

Demikian pula halnya dengan kepercayaan atau persepsi ibu, sebagian besar ibu percaya bahwa memberikan hanya ASI saja bisa mencukupi kebutuhan bayi sampai 6 bulan seperti dapat dilihat pada sitasi dibawah ini:

Susah, Nggak bisa kita beri ASI terus, apalagi harus diperes. Tidak banyak dapatnya, padahal bayinya butuh susu banyak, ya kita tambah dengan susu formula saja supaya cukup.

Kalau ASI terus sepertinya susah mbak, pilih yang praktis dan mudah saja gitu, supaya semua bisa jalan maksudnya

Pertama, mungkin pengetahuan tentang manfaat dari ASI. Kedua, seperti yang dikatakan tadi karena ASI yang keluar sedikit, kasian anaknya dikit dapat susu . (informan ASI tidak eksklusif berpendidikan tinggi)

Menurut Rosenstock, 1974 dalam teori Health Belief Model (HBM) persepsi manusia meliputi persepsi kerentanan individu terhadap suatu penyakit (perceived susceptiblity), persepsi terhadap beratnya suatu penyakit (perceived severity), persepsi individu terhadap keuntungan yang akan diperoleh bila melakukan suatu tindakan (perceived benefits), persepsi indvidu terhadap hambatan-hambatan yang akan dihadapi bila melakukan suatu tindakan (perceived barriers), dan keyakinan individu bahwa dia akan bisa melakukan tindakan atau action tersebut (self efficacy). Persepsi ibu menyusui akan diuraikan seperti di bawah ini.
- Persepsi kerentanan (perceived
susceptiblity)
Persepsi kerentanan terhadap suatu penyakit agar bertindak untuk mengobati atau mencegah penyakitnya. Pemberian ASI secara eksklusif dapat mencegah bayi terserang penyakit infeksi, dan akan berpotensi berisiko terkena penyakit apabila pemberian ASI tidak sampai 6 bulan.

- Persepsi keseriusan (perceived severity)

Persepsi keseriusan penyakit apabila terkena maka konsekuensi yang akan diterima akan berat. Bayi yang tidak mendapatkan ASI secara eksklusif dapat menurunkan daya tahan tubuh bayi sehingga mudah terserang penyakit-penyakit dan berdampak kepada kegagalan pertumbuhan bayi. Kombinasi persepsi kerentanan dan persepsi keseriusan akan menghasilkan persepsi ancaman. Individu akan mengubah perilaku mereka berdasarkan persepsi ancaman yang berasal dari keseriusan penyakit tersebut, yang dikutip Glanz, (2008) dalam buku

"Health Behavior and Health Education; Theory, Research and Practice".

- Persepsi manfaat (perceived benefits)

Melakukan tindakan pencegahan akan bermanfaat jika merasa sangat rentan terhadap penyakit-penyakit, persepsi positif ini sangat berperan penting pada perilaku seseorang dalam mengambil suatu keputusan kesehatan atas dirinya ataupun lingkungannya. Besarnya keuntungan ataupun manfaat yang didapat dari suatu tindakan pencegahan maka akan semakin besar peluang individu tersebut menjalankan tindakan pencegahan penyakit. Akan tetapi bila manfaat yang dirasakan kecil dari suatu tindakan yang akan dilakukan untuk pencegahan akan semakin kecil. Pemberian ASI eksklusif memiliki manfaat bagi bayi seperti meningkatkan daya tahan tubuh bayi, meningkatkan kecerdasan bayi, dengan pemberian ASI eksklusif sampai bayi berusia 6 bulan, akan terjamin tercapainya pengembangan potensi kecerdasan anak secara optimal, ASI mengandung nutriennutrien khusus yang diperlukan otakbayi agar tumbuh optimal. 
- Persepsi kendala (perceived barriers)

Persepsi individu bahwa tidak terlalu banyak konsekuensi negatif bila mengambil tindakan pencegahan dan tidak banyak kendala dalam prosesnya. Adanya kendala dalam pemberian ASI eksklusif seperti puting susu yang pendek/terbenam, payudara bengkak, puting susu yang lecet, produksi ASI kurang, dan ibu bekerja, membuat ibu langsung menganggap bahwa hilangnya peluang untuk menyusui secara eksklusif sehingga dengan alasan kendala ini, ibu memberikan selingan ASI yaitu makanan pendamping ASI dini

- Kepercayaan diri (self efficacy)

Kepercayaan seseorang akan kemampuan untuk melakukan suatu tindakan dengan berhasil. Konsep ini ditambahkan oleh Rosenstock, Strecher, dan Becker tahun 1988 untuk menyempurnakan teori health belief model agar sesuai dengan tantangan perubahan perilaku atau kebiasaan yang tidak sehat, yang dikutip Glanz, (2008) dalam buku "Health Behavior and Health Education; Theory, Research and Practice". Ibu memiliki kepercayaan diri dalam memberikan ASI eksklusif, tetapi pada kenyataannya banyak ibu merasa khawatir pemberian ASI saja selama 6 bulan tidak cukup ini disebabkan oleh bayi masih rewel setelah diberikan ASI, maka ibu mulai memperkenalkan makanan pendamping ASI dini dimaksudkan agar bayi tidak rewel setelah diberi makanan.

\section{Faktor Pemungkin}

Faktor pemungkin adalah faktor-faktor yang mendukung perilaku seseorang. Dalam penelitian ini faktor yang dianggap sebagai faktor-faktor yang mendukung tidak diberikannya ASI eksklusif pada ibu rumah tangga yaitu adalah cara lahir, IMD, rooming in, kondisi bayi, kondisi ibu dan paritas ibu. Seperti ungkapan dibawah ini:

Lima dari tujuh informan ASI tidak eksklusif tidak melakukan IMD. Namun, umumnya tidak IMD ini lebih banyak karena sebab yang seharusnya bisa dihindari yaitu karena bayi dibersihkan dan dibedong.
"Tidak. Setelah lahir bayi dibersihkan dan dibedong baru ditaro di dada ibu......."

"Setelah lahir bayi dibersihkan dan dibedong dulu baru ditempelkan....."

"Tidak langsung... karena setelah lahir bayi dimandikan, dibedong baru dikasih ke ibu...." (informan-informan ASI tidak eksklusif berpendidikan tinggi dan rendah)

Rooming-in atau rawat gabung menjadi salah satu faktor pemungkin yang menjadi kegagalan diberikannya ASI eksklusif dibawah umur 6 bulan. Pada penelitian ini satu informan yang tidak melakukan rooming in, enam sisanya ditempatkan bersama-sama dalam satu kamar dengan bayinya. Perlu digali lebih dalam mengapa ibu-ibu yang sudah rooming-in ini selanjutnya tidak bisa melakukan ASI eksklusif.

Inisiasi menyusu dini (IMD) (early breastfeeding initiation) adalah bayi menyusu segera setelah lahir. Bayi diletakkan di atas perut ibu sehingga terjadi kontak kulit bayi langsung dengan kulit ibunya setidaknya dalam satu jam segera setelah lahir dengan cara bayi merangkak mencari payudara (Roesli, 2005). IMD merupakan salah satu poin pedoman untuk keberhasilan menyusui yang dikemukakan WHO/UNICEF pada tahun 2005 mengenai Breast Feeding Promotion and Support, yaitu: "Mulai menyusui segera setelah lahir (dalam waktu satu jam)" (Kemenkes RI, 2010).

Bayi umumnya mempunyai kemampuan yang tinggi untuk mengisap ASI dari buah dada ibunya. Beberapa jam berikutnya setelah lahir, kemampuan mengisap itu mulai menurun maka sebaiknya bayi disusui segera setelah lahir. Beberapa alasan mengapa dianjurkan agar ibu menyusui bayinya segera setelah lahir yaitu menyusui bayi akan memberikan kepuasan dan ketenangan pada ibu. Beberapa ahli menyatakan bahwa menyusui akan memberikan rasa kebanggaan pada diri ibu bahwa ia telah dapat memberikan kehidupan pada bayinya; hisapan air susu akan mempercepat proses kembalinya uterus ibu ke ukuran yang normal. Pada saat bayi mulai menyusu, 
uterus ibu akan berkontraksi yang kadangkadang menimbulkan rasa nyeri; dan penelitian menunjukkan bayi yang disusui segera setelah lahir (60 menit setelah lahir), lebih jarang menderita infeksi dan keadaan gizinya dalam tahun pertama usianya jauh lebih baik dibanding bayi yang terlambat diberi ASI (Moehji, 1988).

Data nasional di Amerika Serikat menunjukkan bahwa meskipun terjadi peningkatan ibu yang melakukan IMD, tetapi banyak di antaranya yang tidak mampu memenuhi syarat menyusui secara eksklusif sesuai rekomendasi dalam hal ekslusivitas dan lamanya (durasi) menyusui. Angka tertinggi untuk kegagalan ini ditemukan terjadi pada minggu pertama setelah bayi dilahirkan. Persepsi ketidakcukupan ASI adalah alasan yang paling sering dikemukakan oleh ibu-ibu yang berhenti menyusui dan terjadi di sebagian besar populasi di dunia (WHO (2000) dalam Gatti, 2008)

Studi cross-sectional di Taiwan yang dilakukan oleh Huang et al. (2009) mengungkap bahwa IMD memiliki hubungan yang bermakna dengan persepsi ibu terhadap suplai ASI-nya (nilai-p=0,002). Hasil penelitian Aisyah (2009) menunjukkan bahwa salah satu faktor kegagalan praktik pemberian ASI eksklusif disebabkan karena belum adanya praktik pemberian ASI pada satu jam pertama setelah melahirkan. Hal tersebut sejalan dengan penelitian yang dilakukan oleh Fikawati di Wilayah Puskesmas Jagakarsa Jakarta Selatan melaporkan bahwa IMD berpengaruh nyata terhadap pelaksanaan ASI eksklusif. Peran tenaga kesehatan dalam IMD adalah penting (Fikawati, 2010). Dengan IMD, ibu semakin percaya diri untuk tetap memberikan ASInya sehingga tidak merasa perlu untuk memberikan makanan/minuman apapun kepada bayi karena bayi bisa nyaman menempel pada payudara ibu segera setelah lahir (Fikawati, 2009).

Selain hal tersebut diatas alasan lain kegagalan ASI Eksklusif adalah diberikannya makanan-minuman tambahan kepada bayi sebelum berusia 6 bulan bermacam-macam.
Namun demikian, semua penyebabnya bukan karena kondisi yang tidak bisa dihindarkan seperti misalnya sakit. Sebagian informan (tiga dari tujuh informan ASI tidak eksklusif) memberikan makanan-minuman tambahan kepada bayi karena alasan bayi rewel dan terlihat masih haus walaupun habis disusui.

“... bayi rewel, nyusu seperti yang tidak kenyang-kenyang..." (informan ASI tidak eksklusif berpendidikan tinggi)

"Nyusu belum kenyang, mulutnya mangapmangap terus, haus atau gimana gitu..."

"Air susunya sedikit, udah nyusu tapi bayi nangis terus, kayak yang kurang susunya...."

(informan-informan ASI tidak eksklusif berpendidikan rendah)

Dua informan ASI tidak eksklusif sudah memberikan susu formula sejak awal kelahiran karena mendapat susu formula dari bidan. Satu informan karena dibawakan susu oleh bidan sepulang dari puskesmas, sedangkan informan lainnya menyatakan bayinya diberikan susu formula oleh bidan ketika baru dilahirkan tanpa sepengetahuannya.

"Umur 2 bulan coba-coba kasih susu formula. Kan pulang dari puskesmas dikasih susu formula 900 gram.Sayang aja nggak diminum...."

".....susu formula dikasih bidan tanpa sepengetahuan saya, karena bayi nangis terus...." (informan-informan ASI berpendidikan rendah)

Satu informan ASI tidak eksklusif lainnya sudah mulai memberikan pisang kepada bayinya sejak umur 3,5 bulan karena merasa aktivitas bayinya sudah mulai banyak sehingga memerlukan tambahan makanan.

“... pisang sejak umur 3,5 bulan.... Umur 4 bulan ditambah Nestle (bubur susu) ... bayi udah banyak aktivitas dan tenaga. Saya pikir masak dikasih pisang aja..." informan ASI tidak eksklusif berpendidikan tinggi)

Seperti juga dapat terlihat saat proses wawancara mengenai kondisi bayi sehingga ASI ekslusif dihentikan. Sebenarnya tidak ada kondisi khusus dan darurat yang 
mengharuskan informan ASI tidak eksklusif menghentikan pemberian ASI eksklusifnya selain informan merasa bayinya rewel disebabkan karena ASI-nya kurang sehingga masih memerlukan makanan atau minuman tambahan. Seperti yang dikemukakan pada sitasi dibawah ini:

"Bayi rewel, nggak kenyang kalo ASI doang, makanya dikasih pisang. 1 hari 2 kali....."

" Ibunya makan terus dan bayinya nyusu terus. Lapar kali ya, nggak cukup dengan ASI...." (informan-informan ASI tidak eksklusif berpendidikan tinggi)

“..... nyusu belum kenyang, mulutnya mangap-mangap terus, haus atau gimana gitu..."

"Air susunya sedikit, udah nyusu tapi bayi nangis terus, kayak yang kurang susunya....."

(informan-informan ASI tidak eksklusif berpendidikan rendah)

Pada usia di bawah 6 bulan, daya imunitas bayi belum sempurna. Dengan memberikan makanan sebelum usia 6 bulan, berarti membuka kesempatan bagi kumankuman untuk masuk ke dalam tubuh si kecil. Apalagi bila makanan yang diberikan tidak terjamin kebersihannya. Begitu pun dengan alat-alat makan yang digunakan, bila tidak disterilisasi dengan benar akan menimbulkan gangguan kesehatan pada bayi. Berbagai penelitian menunjukkan, bayi yang mendapatkan makanan sebelum usianya 6 bulan ternyata banyak mengalami diare, batuk-pilek, sembelit, demam, ketimbang bayi yang mendapatkan ASI eksklusif. (Irawati, 2010)

Hal tersebut senada dengan penelitian yang dilakukan oleh Purnawati (2001) Proses pemecahan sari-sari makanan dalam tubuh bayi belum sempurna, sehingga bila bayi diberi MPASI sebelum usia 6 bulan, ia berpeluang mengalami obesitas. Pemberian MPASI sebelum usia 6 bulan sering dihubungkan dengan meningkatnya kandungan lemak dan berat badan. Karena itulah, menunda pemberian MPASI sampai usia 6 bulan dapat melindunginya dari obesitas di kemudian hari. Perlu diketahui, beberapa enzim pemecah protein seperti pepsin, lipase, dan amilase, serta asam lambung, baru akan diproduksi sempurna pada saat bayi berusia 6 bulan.

\section{Faktor Penghambat}

Faktor penghambat adalah faktor yang menghambat ibu untuk melakukan praktik ASI ekslusif adalah kondisi ibu, waktu, psikologis ibu, kurangnya dukungan dari tenaga kesehatan (bidan dan dokter) dan keluarga (suami dan orangtua), media serta iklan susu formula. Seperti sitasi dibawah ini: Hambatannya itu ya karena pada saat itu juga sedang sakit, saat anak saya umur 2 bulan saya opname karena saya kekurangan kalium, kalau memberikan ASI kan harus membutuhkan nutrisi yang banyak sementara saya mengalami kekuranga kalium, jalan satu-satunya ya dengan memberikan susu formula

Kayanya kalau saya yang paling ini manajemen waktu dan kemalasan saya kayaknya. saya takut juga kalau ngasi ASI nanti payudara saya jadi lembek. Petugas puskesmas juga ga pernah kesini ngasi tau manfaat ASI

(informan-informan ASI tidak eksklusif berpendidikan tinggi)

Hambatan pemberian salah satunya karena pengaturan waktu yang tidak efektif, yang seharusnya kita mengurus bayi tapi kita banyak kerjaan lain juga yang ada di rumah seperti nyuci, ngepel

Karena ini anak pertama mungkin masalah psilogisnya dari yang tidak punya anak menjadi punya anak

Bagi saya adalah bayi tidak bisa berkembang secara baik dan kedua bayi saya emang ga mau mimik langsung di payudara saya. Ya udah deh dari pada repot saya kasi susu formula aja

(informan-informan ASI tidak eksklusif berpendidikan rendah)

Sembilan informan lainnya tidak pernah mendapat informasi atau penjelasan tentang pentingnya ASI eksklusif. Tenaga kesehatan 
umumnya hanya menasihati informan untuk merawat kehamilannya dengan baik seperti makan makanan bergizi, banyak minum air putih, olahraga ringan, dan mengurangi aktifitas berat.

“...... jaga kondisi, makan makanan bergizi, sering olahraga, minum air putih, susu....."

"Makan, minum susu, olah raga, positif thinking,

banyak kegiatan....." (informan-informan ASI eksklusif berpendidikan tinggi)

"Tidak boleh terlalu capek, harus banyak istirahat dan tidak boleh mengangkat berat, makan teratur, banyak minum air putih. Tidak pernah dijelaskan ten-

tang ASI....." (informan ASI eksklusif berpendidikan rendah)

"Disuruh teratur kalo periksa, obatnya diminum, nggak boleh kecapekan.... Hanya diperiksa aja. Belum dijelasin persiapan menyusui..."

"Menjaga kesehatan, banyak istirahat sembari minum susu, vitamin anak dalam janin...." (informan-informan ASI tidak eksklusif berpendidikan rendah)

Penyuluhan kesehatan merupakan suatu pemberian informasi melalui media komunikasi, informasi dan edukasi dalam meningkatkan penggunaan ASI. Masalah utama dan mendasar dari kegiatan ini adalah para ibu menyusui sangat membutuhkan keyakinan dalam merawat dan menyusui bayi mereka dan keyakinan tersebut bisa mereka dapatkan melalui fasilitas-fasilitas kesehatan dan tambahan informasi yang mendukung (Soetjiningsih, 2004).

Pada waktu ibu memeriksakan kehamilan, para petugas kesehatan dapat menjadikan hal tersebut untuk menyampaikan pesan tentang pentingnya ASI, bagaimana manajeman laktasi dan halhal yang berkaitan dengan kegiatan menyusui. Seiring dengan intensitas ANC yang lebih besar maka akan mempengaruhi ibu untuk menyusui bayinya secara ekslusif.

Faktor penghambat dari keluarga untuk melakukan ASI eksklusif umumnya adalah suami dan orangtua (ibu informan atau mertua perempuan informan). Suami dan orang tua adalah orang terdekat yang dapat mempengaruhi informan untuk tetap menyusui secara eksklusif atau malah memberikan makanan/minuman tambahan kepada bayi.

Sekarang ini mereka tidak mau repot, jadi diberi susu botol. Padahal itukan pemborosan, suami jadi susah utuk cari uang. Padahal air susunya kadang dibuangbuang, tidak diberikan ke bayinya ( Mertua 1)

Perempuan sekarang berbeda, solekannya saja diperhatikan anak kurang diurus, susunya dia tidak diberikan ke anaknya, sibuk-sibuk saja katanya dan malas menampung air susunya untuk anak, jadi anak dikasi susu kaleng. ( Mertua 2)

Kalau ibunya sedang keluar dan kita yang gendong anak merasa kasihan kalau anak nangis, jadi terpaksa diberikan susu botol atau teh karena air susu ibunya tidak disediakan dan disimpan untuk anaknya. (Mertua 3)

Mertua merupakan orang terdekat didalam keluarga, khususnya di Indonesia, keberadaan mertua juga sebagai pengambil keputusan juga sering dimanfaatkan oleh anak atau menantu sebagai orang yang membantu didalam mengurus anak anaknya. Dan sebagai orang tua, mertua juga dapat mempengaruhi ibu di dalam memberikan ASI eksklusif pada bayinya. Hal ini sesuai dengan hasil penelitian yang dilakukan oleh Afifah tahun 2009, dikatakan bahwa faktor eksternal yang mempengaruhi ibu di dalam memberikan ASI non eksklusif adalah adanya dukungan keluarga yaitu ibu, mertua dan suami.

Hanya empat dari tujuh informan ASI tidak eksklusif yang mendapat dukungan dari suami, sisanya mengatakan suaminya menyerahkan keputusan menyusui kepada informan saja.

"Suami terserah saya aja gimana..." (informan ASI tidak eksklusif berpendidikan tinggi)

"Suami terserah kata saya aja.... " 
"Biasa aja, nggak gimana-gimana....." (informan-informan ASI tidak eksklusif berpendidikan rendah)

Saat ditanyakan langsung kepada ibu siapa yang mempengaruhi ibu sehingga memberikan makanan atau minuman tambahan kepada bayi, 3 dari 7 informan ASI tidak eksklusif mengatakan karena orangtua yang menyuruh. Sisanya 4 informan ASI tidak eksklusif mengatakan mereka sendiri yang berinisiatif memberikan karena merasa ASI kurang sehingga bayi menangis terus.

“.... karena orang tua kasihan melihat bayi nyusu sampai muntah-muntah. Nggak kenyang jadi dia minum terus terusan jadi dikasih pisang...."

“...orang tua memberitahu untuk ngasih makanan tambahan, kakak juga dulu begitu...." (informan-informan ASI tidak eksklusif berpendidikan tinggi)

Informan ASI tidak eksklusif, hanya 4 informan saja yang pernah mendapatkan informasi dari media. Media yang mereka lihat atau baca adalah TV, koran, majalah dan buku. Enam dari tujuh informan ASI tidak eksklusif merasa tertarik dengan iklan susu formula. Mereka menyebutkan bahwa iklan susu formula bagus dan menarik, tidak ada salahnya, bagus untuk ibu yang ASI-nya tidak keluar, dan lain sebagainya. Hanya satu informan ASI tidak eksklusif yang menyebutkan bahwa mungkin ASI lebih baik, tapi selebihnya informan tersebut percaya dengan iklan susu formula tersebut.

"Bagus, menarik.... Ada pengaruh pengen anaknya kayak yang diiklan....."

"Nggak ada salahnya. Kalau ASI nggak keluar mau nggak mau dikasih susu formula.

...." (informan-informan ASI tidak eksklusif berpendidikan tinggi)

" Baik, jadi kepengen untuk pertumbuhan anak...." (informan ASI tidak eksklusif berpendidikan rendah)

“ Bagus, buat ibu yang ASI-nya nggak keluar bisa membantu...... Pengaruhnya jadi pengen coba-coba, diiklan anaknya gemuk-gemuk, sehat, cerdas jadi pen-

gen....."(informan ASI tidak eksklusif berpendidikan rendah)
Berdasarkan hasil penelitian ini didapatkan kesuksesan menyusui sangat dipengaruhi orang-orang terdekat sang ibu. Tidak hanya ayah saja, dukungan dari anggota keluarga seperti kakek, nenek, mertua, adik, kakak dan seluruh keluarga besar. Mereka bisa membangkitkan semangat ibu untuk terus menyusui atau justru membuat ibu menyusui ragu dan menyerah sehingga tidak melanjutkan menyusui. Roesli (2005) menyatakan bahwa dukungan keluarga merupakan faktor eksternal yang paling besar pengaruhnya terhadap keberhasilan ASI ekslusif. Adanya dukungan keluarga terutama suami akan berdampak pada peningkatan rasa percaya diri atau motivasi dari ibu dalam menyusui. Suririnah (2004) menyatakan bahwa motivasi seorang ibu sangat menentukan dalam pemberian ASI ekslusif selama 6 bulan. Disebutkan bahwa dorongan dan dukungan dari pemerintah, petugas kesehatan dan dukungan keluarga menjadi penentu timbulnya motivasi ibu dalam menyusui. Selain itu ada juga teori dari Friedman (2010) yang menyatakan bahwa keluarga bisa memberikan dalam berbagai bentuk dukungan seperti, dukungan informasi, dukungan penghargaan, dukungan instrumental dan dukungan emosional. Dukungan tersebut diberikan setiap saat baik saat ibu baru mulai proses kehamilan, proses persalinan, mulai proses menyusui bahkan sampai selesai proses menyusui. Dukungan dalam proses pemberian ASI tersebut dibutuhkan oleh ibu menyusui hingga 2 tahun dan disertai pula dengan perawatan kesehatan dan pemberian dukungan dari keluarga serta lingkungannya (Proverawati, 2010).

Dukungan terbesar yang datangnya dari keluarga adalah dari suami ibu itu sendiri. Suami merupakan elemen utama dalam dukungan yang diberikan kepada ibu menyusui. Dukungan suami bisa memberikan keberhasilan atau kegagalan dalam pemberian ASI karena suami dapat mempengaruhi kondisi emosi ibu menyusui yang ditunjang oleh pemahamaan terhadap pentingnya ASI (Roesli, 2005). Menurut KTT (1990) dukungan keluarga terhadapa 
proses pemberian ASI memiliki peranan yang sangat penting untuk memberikan pemahaman terhadap ibu menyusui agar memberikan ASI kepada bayi sampai 6 bulan pertama kehidupannya. Semakin besar dukungan yang diberikan keluarga, semakin besar juga kesempatan anak untuk bertahan dan diberikan ASI secara ekslusif. Seorang ibu menyusui yang tidak didukung oleh pihak keluarganya untuk memberikan ASI, cenderung akan beralih menggunakan susu formula (Proverawati, 2010).

Hal ini sejalan dengan pernyataan yang dikemukakan oleh Sudiharto (2007) yang menyatakan bahwa dukungan terbesar yang didapat oleh ibu menyusui untuk memberikan ASI ekslusif kepada bayinya didapatkan dari keluarga terdekat. Dukungan keluarga dapat memberikan motivasi kepada ibu menyusui untuk memberikan ASI ekslusif kepada bayinya hingga berusia 6 bulan. Dukungan ini juga bisa dalam bentuk dukungan moral dan psikologi agar ibu selalu memberikan yang terbaik bagi bayinya termasuk pemberian ASI dan nutrisi yang seimbang.

Dukungan keluarga merupakan faktor pendukung yang pada prinsipnya adalah suatu kegiatan baik bersifat emosional maupun psikologis yang diberikan kepada ibu menyusui dalam memberikan ASI. Seorang ibu yang tidak pernah mendapatkan nasehat atau penyuluhan tentang ASI dari keluarganya dapat mempengaruhi sikapnya ketika dia harus menyusui sendiri bayinya (Lubis, 2000). Hasil penelitian yang dilakukan oleh Asmijati (2007) menyebutkan ibu yang mendapat dukungan keluarga memiliki kemungkinan memberikan ASI ekslusif 6.5 kali lebih besar dibanding dengan ibu yang tidak mendapat dukungan keluarga. Penelitian lain juga mengatakan bahwa ibu yang tidak mendapat dukungan keluarga akan meningkatkan risiko untuk tidak memberikan ASI ekslusif (Mardiyanti, 2007).

\section{Simpulan}

Dalam penelitian ini ditemukan beberapa faktor yang menjadi penyebab kegagalan ASI
Eksklusif pada balita usia 6 bulan seperti faktor predisposisi, faktor pemungkin dan faktor penghambat. Ketiga faktor tersebutlah yang menjadi alasan ibu rumah tangga tidak bisa memberikan ASI Eksklusif pada anaknya. Sehingga diperlukan adanya edukasi dan pendekatan dari keluarga dan tenaga kesehatan supaya semua ibu rumah tangga.

\section{Referensi}

Asmijati, 2007. Faktor-faktor yang berhubungan dengan pemberian ASI ekslusif di wilayah kerja puskesmas Tiga raksa Tangerang. FKM UI. Depok.

Bloom, Benjamin S., etc. 1956. Taxonomy of Educational Objectives : The Classification of Educational Goals, Handbook I Cognitive Domain. New York : Longmans, Green and Co.

Cox, S. 2006. Breasfeeding with Confidence, Panduan untuk belajar menyusui dengan percaya diri. Jakarta: PT. Elex Media komputindo.

Depkes RI, 2010, Strategi Nasional Peningkatn Pemberian Air Susu Ibu sampai Tahun 2010, Jakarta: Kerjasama Depdagri, Depkes, Departemen Tenaga Kerja dan Transmigran, Kementrian Negara Pemberdayaan Perempuan, World Health Organization (WHO).

Depkes RI, 2005. Survei kesehatan rumah tangga (SKRT) 2004 vol. 2: Status Kesehatan Masyarakat Indonesia, Jakarta.

Dinas Kesehatan Provinsi Bali. Profil Kesehatan Provinsi Bali 2014.Denpasar: 2014.

Dinas Kesehatan Kabupaten Tabanan. Profil Kesehatan Kabupaten Tabanan 2014.Tabanan: 2014.

Fikawati, S. dan Syafiq, A., 2010. Kajian Implementasi dan Kebijakan Air Susu Ibu Ekslusif dan Inisiasi Menyusu Dini di Indonesia. Makara Kesehatan, Vol. 14, No. 1, Juni 2010: 17-24 . 
Friedman, M., Bowden, V. r., \& Jones, E. G., 2010.Buku Ajar Keperawatan Keluarga; Riset, Teori \& Praktik.Jakarta : EGC

Gatti, Lisa., 2008. Maternal Perceptions of Insufficient Milk Supply in Breastfeeding. Journal of Nursing Scholarship, 2008; 40:4. Sigma Theta Tau International

Green, L. W. Kreutter, M. W. 1991. Health Promoting Planning An Educational And Environmental Approach, Second Edition Mayfield Publishing Company, London, p. 142-147

Irawati, A., 2009. Pola Menyusui dan Status Gizi Ibu Menyusui di Indonesia Breastfeeding Pattern and Nutritional Status of Lactating Mother in Indonesia). Penelitian Gizi dan Makanan (The Journal of Nutrition and Food Research) Volume 32 (Suplemen) 2009. Bogor: Departemen Kesehatan RI, Balitbangkes Pusat Penelitian dan Pengembangan Gizi dan Makanan.

Kementerian Kesehatan RI. 2011. Konselor Menyusui Bantu Tingkatkan Keberhasilan Pemberian ASI. Jakarta: Pusat Komunikasi Publik, Sekretariat Jenderal Kementerian Kesehatan RI.

Kementerian Kesehatan RI. 2014 Acara puncak Pekan ASI Sedunia (PAS) tahun 2014. (online) Avaible at: http://gizi.depkes.go.id/acarapuncak-pekan-asi-sedunia-tahun2014. Diakses tanggal 15 oktober 20115.

Lubis, 2000. Pengaruh pengetahuan keluarga tentang ASI dan sikap ibu di dalam memberikan ASI pada bayinya. Universitas Sumatra Utara. Medan Mardiyanti., 2007. Pengaruh karakteristik dan dukungan keluarga terhadap pemberian ASI ekslusif di Tanggerang. Jurnal Kesehatan Masyarakat Nasional.

Purnamawati, S., 2003. Faktor-Faktor yang Berhubungan Dengan Pola Pemberian ASI Pada Bayi Usia
Empat Bulan (Analisis Data Susenas 2001). Media Litbang Kesehatan Volume XIII Nomor 3 Tahun 2003

Putra, A., 2008 . Analisis Praktek Bidan pada Pelayanan Ibu Bersalin dan Bayi Baru Lahir. KESMAS, Jurnal Kesehatan Masyarakat Nasional Vol. 3 No. 1, Agustus 2008. Depok: FKM UI

Proverawati, A., dan Asfuah, A., 2010. Buku Ajar Gizi untuk Kebidanan.Yogyakarta: Nuha Media

Riset Kesehatan Dasar (Riskesdas). (2010). Cakupan ASI Ekslusif di Indonesia

Riset Kesehatan Dasar (Riskesdas). (2013). Cakupan ASI Ekslusif di Indonesia

Roesli, U., 2010. Mengenal ASI Ekslusif. Jakarta: PT Pustaka Pembangunan Swadaya Nusantara

Soetjiningsih. 1997. Seri Gizi Klinik ASI Petunjuk untuk Tenaga Kesehatan. Jakarta: EGC.

Suririnah. 2009. Buku Pintar Merawat Bayi 0-12 Bulan; Panduan Bagi Ibu Baru Untuk Menjalani Hari - Hari Bahagia dan Menyenangkan BersamaBayinya. Jakarta: Gramedia Pustaka Utama

Susanti. 2000. Hubungan Tingkat Pendidikan dan Pengetahuan Tentang ASI dengan Pemberian Kolostrum dan ASI Ekslusif ( Studi Desa Tidu Kecamatan Bikareja). Semarang: Fakultas Kesehatan Masyarakat Diponegoro 